Notes and Comments

\title{
Seed dispersal of the palm Acrocomia aculeata by the Blue-and-Yellow Macaw (Ara ararauna)
}

\author{
L. B. Silva ${ }^{\mathrm{a}, \mathrm{b} *}$ (), G. A. Pereirac ${ }^{\mathrm{C}}$, P. B. Passos Filho ${ }^{\mathrm{d}}$ and N. M. Almeida ${ }^{\mathrm{a}, \mathrm{b}}$ (1) \\ aUniversidade Federal Rural de Pernambuco - UFRPE, Departamento de Biologia, Programa de Pós-graduação em Biodiversidade, Laboratório \\ de Ecologia Reprodutiva de Angiospermas, Recife, PE, Brasil \\ bUniversidade Estadual de Alagoas - UNEAL, Campus III, Palmeira dos Índios, AL, Brasil \\ 'Universidade Federal Rural de Pernambuco - UFRPE, Departamento de Biologia, Laboratório de Ornitologia, Recife, PE, Brasil \\ dE-fauna - Consultoria Ambiental, Maceió, AL, Brasil
}

The order Psittaciformes comprises 420 species, including parrots, parakeets, cockatoos, lorikeets, pyrrhuras, and macaws (IUCN, 2021). These birds have a peculiar set of characteristics, such as zygodactyl feet, short neck, thick and prehensile tongue, in addition to a strong, tall, and curved beak, specialized in breaking hard seeds (Collar, 1997; Forshaw, 2010).

These animals are traditionally considered important predators of pre-dispersal seeds (Francisco et al., 2002; Trivedi et al., 2004; Haugaasen, 2008). However, recent studies have drawn attention to the importance of Psittaciformes in dispersing diaspores (Tella et al., 2015; Tella et al., 2016; Blanco et al., 2016; Baños-Villalba et al., 2017; Blanco et al., 2018; Tella et al., 2019; Tella et al., 2020). In the Neotropical region, information about these interactions are still scarce (Tella et al., 2016, 2020; Bravo et al., 2020). In the present study, we recorded the primary dispersal of seeds of the macaw palm, Acrocomia aculeate (Jacq.) Lodd. ex Mart. (Arecaceae), by the Blue-and-yellow Macaw, (Ara ararauna) (Linnaeus, $1758)$ in the Brazilian Cerrado.

The records were carried out in Caiapó Mountain Range ( $17^{\circ} 09^{\prime} 45^{\prime \prime}$ S, $51^{\circ} 20^{\prime} 06^{\prime \prime} \mathrm{W} ; 572 \mathrm{~m}$ a.s.l.), in the municipality of Caiapônia, state of Goiás, Brazil. Observations took place in a pasture area inserted in the cerrado stricto sensu, during the months of March and May 2015, from 8h00 to 11h00 and from $14 \mathrm{~h} 00$ to $17 \mathrm{~h} 00$, totaling $28 \mathrm{~h}$ of observations, performed during 10 no-consecutive sunny days. We used binoculars with magnitudes of $8 \times 42 \mathrm{~mm}$ to observe the details of the interaction, cameras to record it and a GPS device to estimate the dispersion distance.

The Blue-and-yellow Macaw is a large-sized parrot, reaching up to $86 \mathrm{~cm}$ in length with body mass ranging from 995 to $1380 \mathrm{~g}$. It is one of the psittacids with the broadest geographical distribution, occurring in eastern Panama to Colombia, Venezuela, Guyana, Ecuador, Peru, Bolivia, and Paraguay. It occurs in almost all Brazil, including the North, Northeast and Midwest regions (BirdLife International, 2021). Although it is not included in national and international red lists, the Blue-and-yellow Macaw is in decline in several places and became extinct in some areas of its original distribution (Caparroz, 2003). Its diet consists of fruits and seeds of several plant species, as well as flowers and leaves, and even nectar (Collar, 1997).

The macaw palm (Acrocomia aculeata), also known as macaúba palm, coyol palm, among other common names, is a native species in several tropical environments, whose stems can reach 10 to $15 \mathrm{~m}$ in height and 20 to $30 \mathrm{~cm}$ in diameter (Lorenzi et al., 2010). Fruits have a globose shape and are composed of a hard epicarp, a fibrous and mucilaginous mesocarp, and a woody endocarp, firmly adhered to the mesocarp (Lorenzi et al., 2010).

We collected 30 ripe fruits at random from three individuals ( 10 from each tree), with a minimum distance of $30 \mathrm{~m}$ between them, to obtain morphometric data and proportion (\%) of pulp (mesocarp). We measured the length (distance between the insertion of the peduncle and the apex) and the diameter (greatest distance perpendicular to the axis) of fruits and seeds (seed surrounded by the endocarp). We used a caliper with $0.1 \mathrm{~mm}$ precision for measurements. We calculated the proportion of pulp based on the relationship between the total mass of whole fruits and the mass of the pulp. We measured masses using a scale with $0.1 \mathrm{~g}$ precision.

We recorded 22 events of primary dispersion of seeds of the macaw palm by the blue-and-yellow macaw. In all records, the macaws searched for ripe fruits on the trees and used the beak to pluck them at the peduncle (Figure 1). Next, they flew with the fruit in their beak to trees of other species, 40 to $300 \mathrm{~m}$ far from the mother plant (Figure 2). While perched, the birds held the fruit with one foot and removed the epicarp with the beak. Then, they fed on the pulp and discarded the whole seed. It was also possible to observe that the discarded seeds had scarifications on the endocarp, caused by the beak during the removal of the pulp.

The fruits had, on average, $46.08 \pm 2.28 \mathrm{~mm}$ in diameter and $41.40 \pm 2.45 \mathrm{~mm}$ in length, and $31.34 \%$ of pulp. The seeds had, on average, $33.16 \pm 2.78 \mathrm{~mm}$ in diameter and $28.48 \pm 2.07 \mathrm{~mm}$ in length. These attributes classified these

*e-mail: lb_silva@yahoo.com.br

Received: October 18, 2020 - Accepted: February 12, 2021 

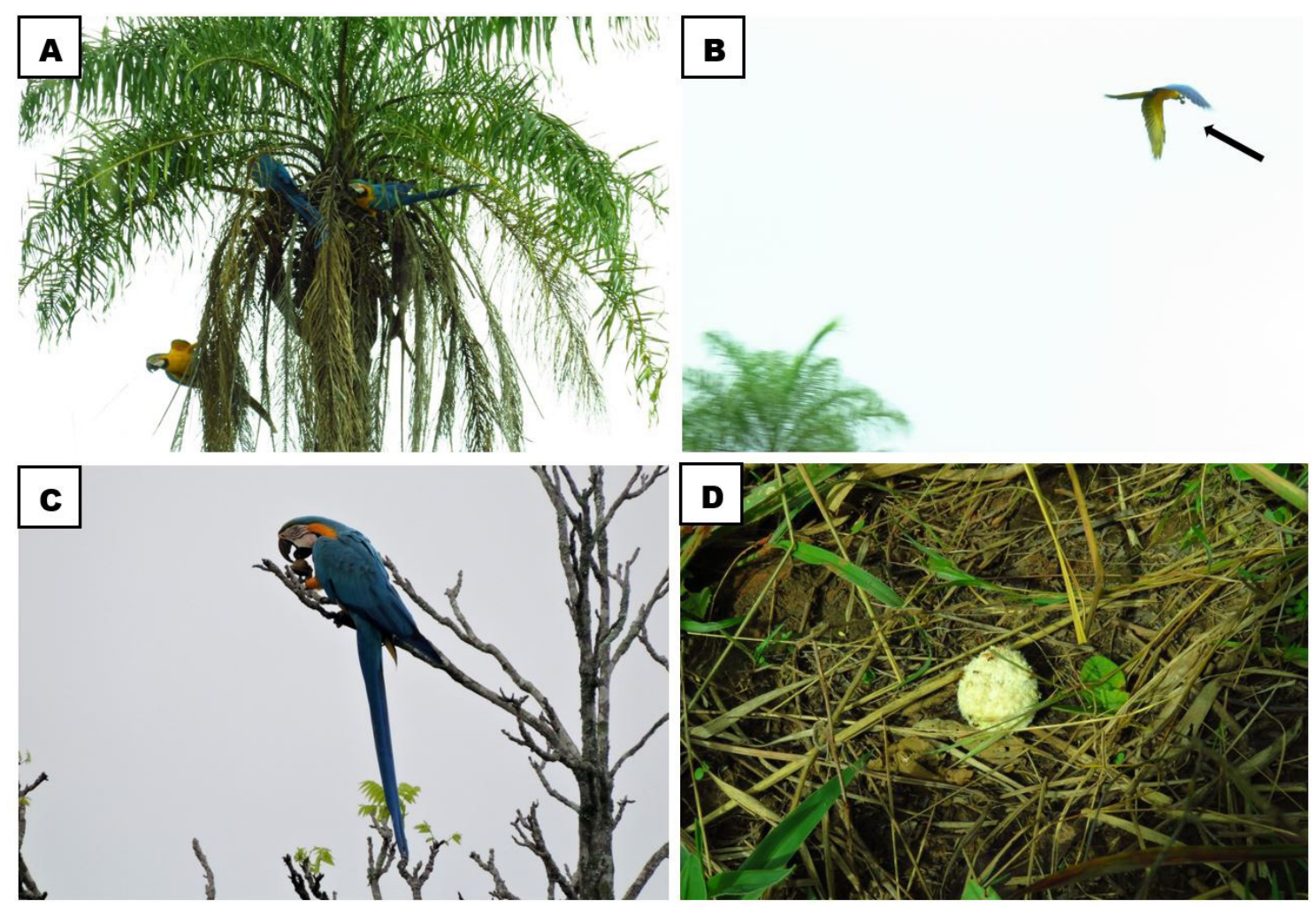

Figure 1. Seed dispersal of the macaw palm, (Acrocomia aculeata), by the Blue-and-yellow Macaw (Ara ararauna) in a Cerrado area in the state of Goiás, Brazil. (A) Blue-and-yellow Macaws collecting fruits; (B) Blue-and-yellow Macaw flying with the fruit in its beak; (C) Blue-and-yellow Macaw feeding on the pulp; (D) Seed discarded by the Blue-and-yellow Macaw. Photos: Leonardo B da Silva (A, B, and D) and Glauco A. Pereira ${ }^{\circ}$.

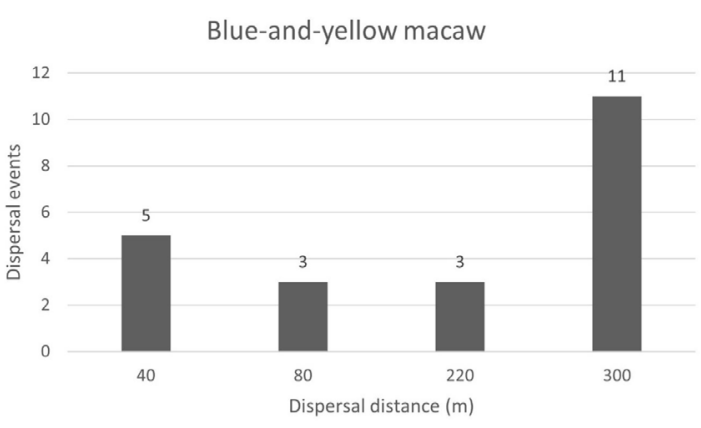

Figure 2. Distribution of seed dispersal distances of the macaw palm, (Acrocomia aculeata), by the Blue-and-yellow Macaw (Ara ararauna) in a Cerrado area in the state of Goiás, Brazil.

fruits into the so-called "megafauna syndrome", that is, large fruits whose seeds are dispersed by large terrestrial vertebrates (Guimarães Junior et al., 2008). However, our records (100\%) showed that the blue-and-yellow macaw could be an efficient disperser of these diaspores, as it showed great ability in collecting and transporting them to places far from the mother plant. This ability to disperse great fruits over long distances, was also observed for other species of macaws (see Baños-Villalba et al., 2017; Blanco et al., 2019; Tella et al., 2020).
In the family Arecaceae, species propagate mainly through seeds, but, in general, their germination is slow, occurs at a low percentage and under the influence of several factors, such as the physical dormancy imposed by the woody endocarp (Lorenzi et al., 2010; Neves et al., 2013). Scarification caused by macaws during the removal of the pulp is an intervention that may increase the germination speed and rate, as the endocarp surface may be exposed to water and gases (Lorenzi et al., 2010). In sites where birds discarded seeds, it was possible to observe some seedlings of the macaw palm, suggesting successful seed dispersion by blue-and-yellow macaws. In fact, the perches used by macaws during feeding can have a positive relationship with the special distribution of immature palms (Baños-Villalba et al., 2017; Tella et al., 2020).

Macaws can perch for a long time on the same tree while feeding (about 30 minutes; personal observation). However, in our study, we observed that the crown of the macaw palm trees did not provide a stable structure for birds to perch while feeding, which forced them to fly with the fruit in their beak to trees bearing stable perches. After eating the pulp, birds returned to collect more fruits. This behavior was repeated several times and probably resulted from the low proportion of pulp of macaw palm fruits, so that macaws had to collect a large number of fruits during feeding activity. 
As psittacids are widely known as seed predators, they have been neglected as dispersers (Blanco et al., 2016; Montesinos-Navarro et al., 2017; Blanco et al., 2018; Tella et al., 2019). Despite that, macaws can be efficient in dispersing large diaspores, as they can collect and transport them over long distances. In a scenario of intense defaunation, it is important to look at the role of psittacids in seed dispersal process, these birds can occupy a niche left by large frugivorous vertebrates (Tella et al., 2020). Therefore, studies that investigate the fruit diet and feeding behavior of these animals in the wild, associated with the reproductive ecology of plants, are necessary to answer questions such as: what is the importance of these birds for the recovery of degraded areas? and what are the consequences of breaking these ecological interactions?

\section{Acknowledgements}

The authors thank the Messias Perez and Ms. Cida, for their kind hospitality and help in the fieldwork, and Agricert Agro Mercantil Ltda., for financial and logistical support.

\section{References}

BAÑOS-VILLALBA, A., BLANCO, G., DÍAZ-LUQUE, J.A., DÉNES, F.V., HIRALDO, F. and TELLA, J.L..2017. Seed dispersal by macaws shapes the landscape of an Amazonian ecosystem. Scientific Reports, vol. 7, no. 1, pp. 7373. http://dx.doi.org/10.1038/s41598017-07697-5. PMid:28785083.

BIRDLIFE INTERNATIONAL, 2021. [viewed 28 January 2021]. Species factsheet: Ara ararauna [online]. Available from: http://www. birdlife.org/

BLANCO, G., BRAVO, C., PACÍFICO, E.C., CHAMORRO, D., SPEZIALE, K.L., LAMBERTUCCI, S.A., HIRALDO, F. and TELLA, J.L., 2016. Internal seed dispersal by parrots: an overview of a neglected mutualism. PeerJ, vol. 4, pp. e1688. http://dx.doi.org/10.7717/ peerj.1688. PMid:26925322.

BLANCO, G., HIRALDO, G. and TELLA, J.L., 2018. Ecological functions of parrots: an integrative perspective from plant life cycle to ecosystem functioning. The Emu, vol. 118, no. 1, pp. 36-49. http://dx.doi.org/10.1080/01584197.2017.1387031.

BLANCO, G., TELLA, J.L., DÍAZ-LUQUE, J.A. and HIRALDO, F., 2019. Multiple external seed dispersers challenge the megafaunal syndrome anachronism and the surrogate ecological function of livestock. Frontiers in Ecology and Evolution, vol. 7, no. 328, pp. 1-17. http://dx.doi.org/10.3389/fevo.2019.00328.

BRAVO, C., CHAMORRO, D., HIRALDO, F., SPEZIALE, K., LAMBERTUCCI, S. A., TELLA, J. L. and BLANCO, G., 2020. Physiological dormancy broken by endozoochory: Austral parakeets (Enicognathus ferrugineus) as legitimate dispersers of calafate (Berberis microphylla) in the Patagonian Andes. Journal of Plant Ecology, vol. 13 , no. 5, pp. 538-544.

CAPARROZ, R., 2003. Filogeografia, estrutura e variabilidade genética da arara-canindé (Ara ararauna, Psittaciformes: Aves) no Brasil baseadas na análise de DNA mitocondrial e de DNA nuclear. São Paulo: Universidade de São Paulo, 98 p. Tese de Doutorado em Ciências.
COLLAR, N.J., 1997. Family Psittacidae (parrots). In: J. DEL HOYO, J. A. ELLIOT. and J. SARGATAL, eds. Handbook of the birds of the world. Barcelona: Lynx Edicions, pp. 280-477, vol. 4: Sangrouse to cuckoos.

FORSHAW, J.M., 2010. Parrots of the world. Oxford: Princenton University Press.

FRANCISCO, M.R., OLIVEIRA LUNARDI, V. and GALETTI, M., 2002. Massive seeds predation of Pseudo bombax grandiflorum (Bombacaceae) by parakeets Brotogeris versicolurus (Psittacidae) in a forest fragment in Brazil. Biotropica, vol. 34, no. 4, pp. 613615. http://dx.doi.org/10.1111/j.1744-7429.2002.tb00582.x.

GUIMARÃES JUNIOR, P.R., GALETTI, M. and JORDANO, P., 2008. Seed dispersal anachronisms: rethinking the fruits extinct megafauna ate. PLoS One, vol. 3, no. 3, pp. e1745. http://dx.doi. org/10.1371/journal.pone.0001745. PMid:18320062.

HAUGAASEN, T., 2008. Seed predation of Couratari guianensis (Lecythidaceae) by macaws in central Amazonia, Brazil. Ornitologia Neotropical, vol. 19, no. 3, pp. 321-328.

INTERNATIONAL UNION FOR CONSERVATION OF NATURE IUCN, 2021 [viewed 28 January 2021]. Red List of Threatened Species, Version 2019-3 [online]. Available from: http://www. iucnredlist.org/

LORENZI, H., NOBLICK, L.K., KAHN, F. and FERREIRA, E., 2010. Flora Brasileira: Arecaceae (palmeiras). Plantarum: São Paulo.

MONTESINOS-NAVARRO, A., HIRALDO, F., TELLA, J.L. and BLANCO, G., 2017. Network structure embracing mutualismo-antagonism continuum increases Community robustness. Nature Ecology $\mathcal{E}$ Evolution, vol. 1, no. 11, pp. 1661-1669. http://dx.doi.org/10.1038/ s41559-017-0320-6. PMid:28970589.

NEVES, S.C., RIBEIRO, L.M., DA CUNHA, I.R.G., PIMENTA, M.A.S., MERCADANTE-SIMÕES, M.O. and LOPES, P.S.N., 2013. Diaspore structure and germination ecophysiology of the babassu palm (Attaleavitrivir). Flora, vol. 208, no. 1, pp. 68-78. http://dx.doi. org/10.1016/j.flora.2012.12.007.

TELLA, J.L., BAÑOS-VILLALBA, A., HERNÁNDEZ-BRITO, D., ROJAS, A., PACÍFICO, E., DÍAZ-LUQUE, J.A., CARRETE, M., BLANCO, G. and HIRALDO, F., 2015. Parrots as overlooked seed dispersers. Frontiers in Ecology and the Environment, vol. 13, no. 6, pp. 338339. http://dx.doi.org/10.1890/1540-9295-13.6.338.

TELLA, J.L., BLANCO, G., DÉNES, F.V. and HIRALDO, F., 2019. Overlooked parrot seed dispersal in australia and south america: insights on the evolution of dispersal syndromes and seed size in Araucaria trees. Frontiers in Ecology and Evolution, vol. 7, no. 82, pp. 1-10. http://dx.doi.org/10.3389/fevo.2019.00082.

TELLA, J.L., DÉNES, F.V., ZULIAN, V., PRESTES, N.P., MARTíNEZ, J., BLANCO, G. and HIRALDO, F., 2016. Endangered plant-parrot mutualisms: seed tolerance to predation makes parrots pervasive dispersers of the Parana pine. Scientific Reports, vol. 6, no. 1, pp. 31709. http://dx.doi.org/10.1038/srep31709. PMid:27546381.

TELLA, J.L., HIRALDO, F., PACÍFICO, E., DÍAZ-LUQUE, J.A., DÉNES, F.V., FONTOURA, F.M., GUEDES, N. and BLANCO, G., 2020. Conserving the diversity of ecological interactions: the role of two threatened macaw species as legitimate dispersers of “Megafaunal" fruits. Diversity (Basel), vol. 12, no. 45, pp. 1-20. http://dx.doi.org/10.3390/d12020045.

TRIVEDI, M.R., CORNEJO, F.H. and WATKINSON, A.R., 2004. Seed predation on Brazil nuts (Berthollethia excelsa) by macaws (Psittacidae) in Madre de Dios, Peru. Biotropica, vol. 36, no. 1, pp. 118-122. 